\title{
Statistical evaluation of the geochemical variability in overbank sediments in Spain
}

\author{
Paula Adánez Sanjuán ${ }^{1}$ D · Marcelo Ortega ${ }^{2}$ Juan F. Llamas Borrajo ${ }^{2}$ Juan Locutura Rupérez ${ }^{1}$ - Ángel García Cortés ${ }^{1}$
}

\begin{abstract}
The overall objective of this study is to estimate, detect and specify the main sources of variance which affect the contents of the different elements in overbank sediments across Spain. These sources of variance were assessed and compared by means of a series of analyses of variance (ANOVAs), by regarding two parameters: their significance and their contribution to the total variance. Overbank sediments, sampled in erosion banks, were studied in several locations, in basins which drain different types of geological backgrounds and land uses (urban, mining, agricultural or pristine) across the Iberian Peninsula. Forty-eight elements (mostly in the $<63 \mu \mathrm{m}$ fraction) were analysed by ICP-OES, ICP-MS and INAA. After an isometric $\log$ ratio (ilr) transformation of the data, three ANOVA analyses were performed considering three perspectives: (1) local scale, (2) regional scale: within-profile perspective and (3) regional scale: inter-profile perspective. On a local scale, it was observed that the variability of rare earth elements (REE) depends mostly on the grain size and that heavy metals are also influenced by depth. In the analysis carried out on a regional scale, from a within-profile perspective, depth and duplicates do not influence significantly the variability of the element contents. Finally, from an inter-profile perspective, the selected sources of variance were land use and provenance, whose significance is the highest. While grain size and the selection of depth are of crucial importance in the final results, on local studies, land use and provenance are the ones that influence the most the composition of sediments in regional studies.
\end{abstract}

Keywords ANOVA analysis · Geochemistry · Ilr transformation · Overbank sediments · Regional/local scale · Spain

\section{Introduction}

In this study, overbank sediments are considered as the sediments formed by vertical accretion when water exceeds riverbanks during a flood, following the definition by Wolman and Leopold (1957). Their importance for geochemical studies was first established by Ottesen et al. (1989). They stated that these types of sediments are more representative than stream sediments and can build a historical register of the chemical and mineralogical conditions during the successive floods that

Paula Adánez Sanjuán

paula.adanez@gmail.com

1 Geological Survey of Spain (IGME), Ríos Rosas, 23, 28003 Madrid, Spain

2 E.T.S.I. Minas y Energía, Madrid, Ríos Rosas, 21, 28003 Madrid, Spain have formed the profile. In their view, uppermost overbank sediments reflect recent conditions of contamination while lowermost overbank sediments reflect preindustrial or natural conditions. However, other authors such as Macklin et al. (1994) or Ridgway et al. (1995) state that this is not so simple and that a thorough investigation of the sampling site must be carried out to ensure reliable results. Demetriades and Volden (1997) made it clear that a careful sampling practice is extremely important in overbank sediments. Overbank sediments are described as both sinks of contaminants, which are adsorbed on the fine grains and also as a risk associated with a possible remobilisation that could turn these sediments into sources of contamination (Macklin 1996; Walling et al. 1996; Taylor and Owens 2009; Barać et al. 2016; Matys Grygar and Popelka 2016).

Overbank sediments across Spain are formed in very different circumstances depending on the location due to the highly variable climate conditions across the Iberian Peninsula. In places where the climate is mostly Mediterranean, floods can be very violent and occur with greater time lapses between 
flood events. This is reflected, for example, in a coarser grain size in some of the overbank profiles, as well as in the thickness of the sediment layers deposited in each flood event. Conversely, in the northern part of the Peninsula, where the climate is mostly wet and cold, grain size is finer and sediments are deposited in narrower layers.

Sixteen overbank profiles were sampled across the Iberian Peninsula in 14 drainage basins (Fig. 1). There are many types of lithologies, which provide material to the selected overbank profiles. These profiles were also located in a wide variety of land uses, namely, industrial, urban, mining, agricultural uses and uses with low anthropogenic activity in scarcely populated areas. Thus, there is a high variability in the composition of overbank sediments across Spain (Adánez 2012, Locutura et al. 2012).

The main objective was to study and analyse the major sources of variance in the composition of this type of sediments. The study took into account many possible sources of variance that could alter the results of a research. Different combinations were applied, recognising the following sources of variance: duplicates, granulometric fractions, depth, land use and provenance.

\section{Description of the drainage basins}

The studied basins are Besaya (Cantabria), Majones (Huesca), Arba (Zaragoza), Besós (Barcelona), Zapardiel (Valladolid), Adaja (Ávila), Manzanares, Guadarrama and Jarama (Madrid), Bonhabal (Badajoz), Valdeazogues (Ciudad Real), Guadajoz (Córdoba) and Odiel and Tinto (Huelva). The size of the catchment areas from the studied sampling points average from 1000 to $2000 \mathrm{~km}^{2}$, except for Majones and Adaja (Fig. 1), considered as pristine sediments.

They were selected because of their interest regarding their exposure to different anthropogenic activities and land uses, location, geology, etc. These basins reflect some of the most representative characteristics found in the Iberian Peninsula.

In the north of Spain, the Besaya River (Cantabria) is a highly contaminated river that drains an important industrial area as well as the Reocin mining district, where $\mathrm{Zn}$ and $\mathrm{Pb}$ were exploited until 2003. Mainly sandstone, limestone and marls outcrop in the basin.

The Majones River is a little river in the Pyrenees where the population is very scarce, and there is no significant source of

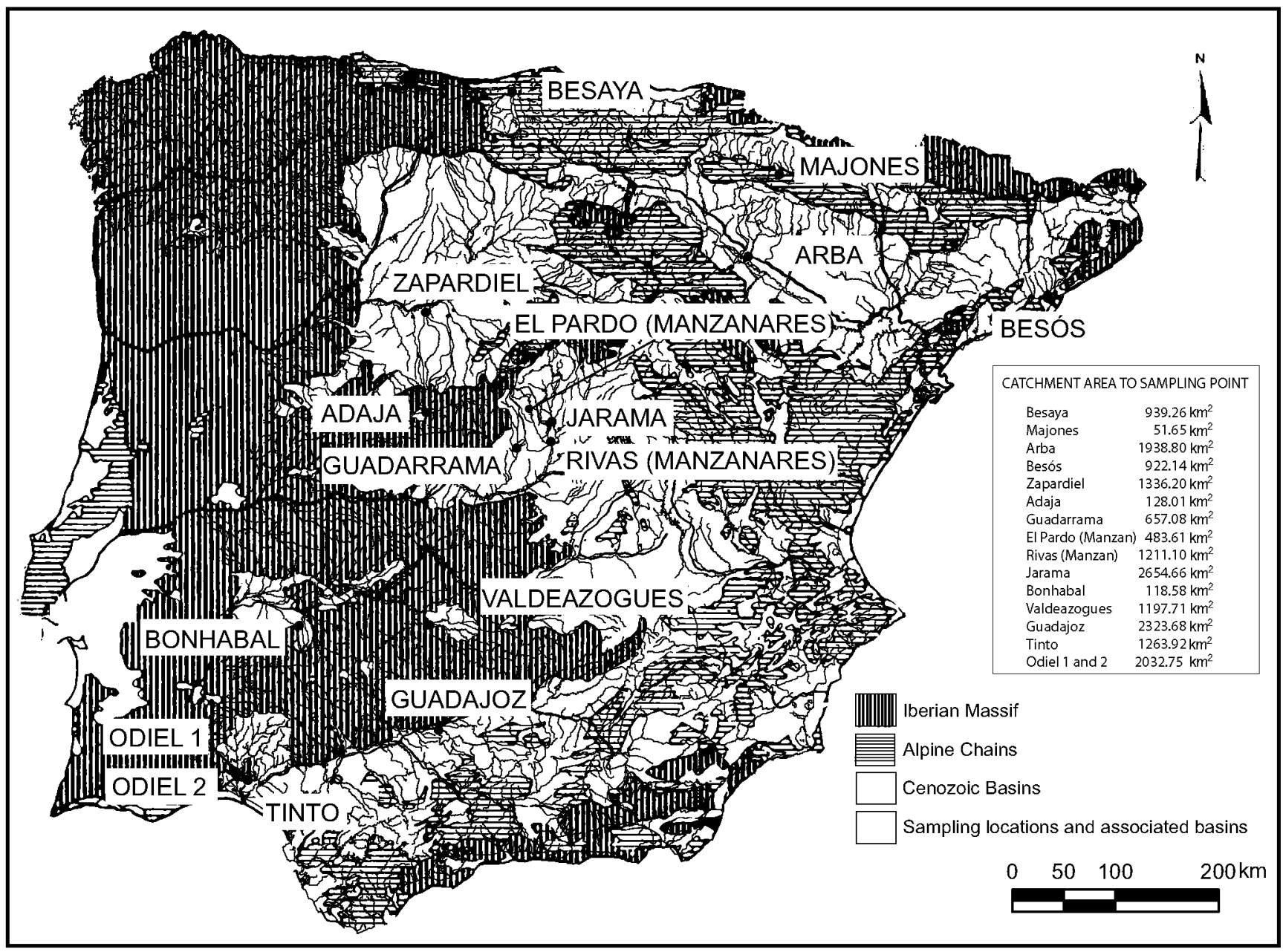

Fig. 1 Schematic map of the Iberian Peninsula showing the position and geology of the studied profiles and their respective catchment areas 
contamination. The materials outcropping in the basin are clays, limestone and marls from a flysch series.

The Arba River is located in the Ebro Basin (Zaragoza) and it drains arkoses, fine sands, clays and marls. The land use here is aimed at agriculture.

The Besós River, located in the surroundings of Barcelona city, crosses an intensely industrialised and crowded area because of which, this river was the most contaminated in Europe during the $70 \mathrm{~s}$ and $80 \mathrm{~s}$ (Huertas et al. 2006). The materials that outcrop in the basin are mainly clays, sandstones, conglomerates, marls and limestone.

The Zapardiel River is located in the Duero Basin. It drains arkoses and sandstones from the Tertiary. This river has a high agricultural activity in its basin.

The Adaja River was sampled near the headwaters to avoid any type of contamination, in order to use this profile as pristine sediments for comparison. Therefore, the covered catchment area down to the sampling point is much smaller than the surface of the whole basin. The materials that outcrop in the basin are mainly granites. In this location, population density is low and anthropogenic activity is mainly cattle.

Three rivers were selected in the Community of Madrid. The Manzanares and the Guadarrama rivers flow almost parallel, but the Manzanares River is the one which crosses the city of Madrid, which is heavily industrialised. Their headwaters are located in the north of the Community, in the Spanish Central System (SCS), composed mainly of granitic plutons. The southern part is formed by Neogene materials of the Tagus Basin. They are primarily arkoses, clays, sands and sandstone, gypsum and marls. In the city of Madrid, in the Manzanares River, two profiles were sampled: El Pardo, upstream, and Rivas, downstream. The Jarama River also crosses some metamorphic rocks like quartzite and schist, as well as limestones and marls that outcrop in its basin.

The Bonhabal River basin (Extremadura), located in the Guadiana Basin, drains some mining traces of $\mathrm{Zn}-\mathrm{Pb}$ near the basin. Its bedrock geology is formed by arkoses, greywacke, shale, limestone and marble. Granites and gneises outcrop as well. These materials are covered by sands.

The Valdeazogues River (Guadiana Basin) drains the Almadén mercury mining district in central Spain which can be regarded as the largest geochemical anomaly of mercury known on Earth. This river is highly affected by the mining activity developed in the area (Higueras et al. 2003). The material drained by the river consists mainly of shale, sandstone, quartzite and greywacke.

The Guadajoz River is located in the Guadalquivir Basin and, with intense olive tree farming, it drains clays, gypsum, dolomites and limestone.

And finally, in the southern part of the Peninsula, the Tinto and the Odiel rivers drain the Iberian Pyrite Belt (IPB), which hosts one of the biggest metallogenic provinces in the world. Pyrite is the main mineral in these deposits, with lower quantities of sphalerite, galena, chalcopyrite, tetrahedrite, arsenopyrite and pyrrhotite (Leistel et al. 1998; Sáez et al. 1999). Manganese deposits have been mined too. These rivers are affected by Acid Mine Drainage and are highly contaminated (Sánchez España et al. 2005; Cánovas et al. 2008).

\section{Methodology}

\section{Sampling procedure and analyses}

Samples correspond to the uppermost and lowermost parts of the vertical profiles sampled for the Geochemical Atlas of Spain (Adánez 2012; Locutura et al. 2012).

Prior to sampling, field studies were made in order to select the most representative profiles. Samples in all the studied basins were taken in the current floodplain and correspond to erosion banks, with characteristics that can be associated to the definition of levee deposits by Allen (1965). These locations are usually the most suitable, as they provide a better sedimentary register as well as thicker sediment layers (Pizzuto 1987). From a geochemical point of view, these locations are supposed to present higher metal concentrations (Langedal 1996) but coarser grain size (He and Walling 1997) than samples taken further away from the channel.

Due to the difficulty in finding a good representation of these sediments, field research was carefully carried out. In general, the best places to sample were the concave banks of the streams, where erosion had exposed the deposition sequence of the successive flood events. Selection of the sampling location was done under certain restraints (no anthropogenic activity had changed the channel or floodplain structure, no reworked material was detected and horizontal strata were recognised). Horizontally deposited sediments were differentiated by net changes of strata or changes in grain size. Most of the sampled profiles were located over lateral accretion deposits, which differed from the vertical accretion deposits due to the coarse grain size (big quantity of gravel and pebbles with no clear stratification). These lateral accretion deposits had a high similarity with the rest of the channel bars formed along the rivers.

Once a well-developed deposition profile had been found and examined, the sampling was carried out. The first centimetres of the exposed surface were removed to avoid pedogenic material and plant debris. Samples were taken by cutting with a spade the stretches through the exposed overbank sediment sequence. The thickness of the samples varied according to the characteristics of the overbank layers, with an average of 20 to $30 \mathrm{~cm}$. One sample usually corresponded to a composite of several flood layers. Bottom samples corresponded to the $20-30 \mathrm{~cm}$ above the lateral accretion deposits or above the water level (in the cases in which it was not possible to get deeper) and vertically, they were taken below the top sample. 
In Adánez (2012) and Adánez Sanjuán et al. (2014a, b, 2016), there is a thorough description of the structures of the profiles. In these studies, it was detected that for example, in Rivas profile in Manzanares River, a radiocarbon dating of charcoal fragments yielded a conventional radiocarbon age of $170 \pm 40{ }^{14} \mathrm{C}$ years $\mathrm{BP}$ at $2.50 \mathrm{~m}$ depth, or that a wide shift in metal contents in Tinto profile at $0.85 \mathrm{~m}$ depth was related to the beginning of an intense mining activity 125 years ago.

The sampled materials were dried in an oven at $40^{\circ} \mathrm{C}$ for nearly a week. Afterwards, they were disaggregated and sieved to $\mathrm{a}<63-\mu \mathrm{m}$ grain size fraction. The same procedure was followed with the samples taken for the local-scale study excepting the fact that these samples were sieved to six granulometric fractions $(<63,63-125,125-177,177-250$, $250-500$ and $>500 \mu \mathrm{m}$ ). All of them were grounded to $<$ $63 \mu \mathrm{m}$ in an agate mill for a subsequent total analysis.

The analyses were carried out at Actlabs Laboratories (Ontario, Canada). The analyses of the total contents of 48 chemical elements (Ag, $\mathrm{Al} \mathrm{As,} \mathrm{Au}, \mathrm{Ba}, \mathrm{Be}, \mathrm{Bi}, \mathrm{Br}, \mathrm{Ca}, \mathrm{Cd}$, $\mathrm{Ce}, \mathrm{Co}, \mathrm{Cr}, \mathrm{Cs}, \mathrm{Cu}, \mathrm{Eu}, \mathrm{Fe}, \mathrm{Ge}, \mathrm{Hf}, \mathrm{K}$, La, Li, Lu, Mg, Mn, Na, $\mathrm{Nd}, \mathrm{Ni}, \mathrm{P}, \mathrm{Pb}, \mathrm{Rb}, \mathrm{Re}, \mathrm{S}, \mathrm{Sb}, \mathrm{Sc}, \mathrm{Se}, \mathrm{Sm}, \mathrm{Sn}, \mathrm{Sr}, \mathrm{Ta}, \mathrm{Th}, \mathrm{Ti}, \mathrm{Tl}$, $\mathrm{U}, \mathrm{V}, \mathrm{Y}, \mathrm{Yb}, \mathrm{Zn}$ ) were carried out by a combination of ICPOES, ICP-MS and INAA. When applying ICP-OES and ICPMS, a 0.25 -g aliquot of sample is digested in $\mathrm{HClO}_{4}-\mathrm{HNO}_{3}-$ $\mathrm{HCl}-\mathrm{HF}$ at $260^{\circ} \mathrm{C}$ to fuming and is diluted with dilute $\mathrm{HCl}$. Quality control for the digestion involved $14 \%$ replicates for each batch, 5 method reagent blanks, 10 in-house controls, 10 samples duplicates and 8 certified reference materials. An additional $13 \%$ of replicates for quality control are performed as part of the instrumental analysis to ensure quality in the areas of instrumental drift. The elemental concentrations agreed acceptably well in each pair of replicates, relative standard deviations averaged $13.5 \%$ for all the analysed elements. Further information can be found on www.actlabs.com.

\section{Data analysis}

This work was done through several univariate analyses of variance (ANOVAs), by using the statistical package $R$ ( $R$ Core Team 2014), in which several sources of variance were taken into account.

With the aim of having uniform data, an isometric log ratio (ilr) transformation was used (Filzmoser et al. 2009), since compositional data can never be seen as truly univariate data, even if only one component is measured. According to Filzmoser et al. (2009) and due to the definition of compositional data, all the relevant information about an element $\left(\mathrm{x}_{1}\right)$ is contained in the ratios to each of the remaining elements (parts: $\mathrm{x}_{2}, \ldots, \mathrm{x}_{\mathrm{D}}$ ). Accordingly, this relative information for all remaining parts needs to be considered also for univariate data analysis. The ilr transformation can be used for this purpose. The ilr variable $\left(z_{1}\right)$ contains all the relative information between $\mathrm{x}_{1}$ and $\mathrm{x}_{2}, \ldots, \mathrm{x}_{\mathrm{D}}$, because none of $\mathrm{z}_{2}, \ldots, \mathrm{z}_{\mathrm{D}-1}$ includes $\mathrm{x}_{1}$. In this way, each compositional part can be expressed by a single ilr variable which can be used for univariate analysis. The variable constructed can be directly used for plotting the histogram, boxplot and density trace, and it can also be directly used for tests referring to the data distribution. Figure 2 proves that the isometric $\log$ ratio transformation is able to change the initial distribution of the raw data into a normal distribution.

Three univariate analyses of variance have been carried out after the transformation, considering different scales and perspectives. The results considered for further conclusions are the $p$ values and the percentages of variance provided by each source. $P$ values represent the significance of each source of variance, where the variability among populations and the intrinsic variability of the observations are compared. The percentage of variance supplied by each source of variance gives information about which of them influences the elemental composition of the samples the most. There is a factor called residuals created automatically by the $\mathrm{R}$ package. Theoretically, this factor gathers all the possible sources of variance that were not taken into account for this study.

\section{Results and discussion}

This study was carried out under three different perspectives. In each perspective, hypothesis tests were posed by considering for each case the sources of variance that may affect the composition of sediments.

In the first stage, a local scale was considered and Rivas profile (in Manzanares River) was studied alone. The sources of variance taken into account in this profile were the ones usually studied in these sample media: duplicates (Demetriades and Volden 1997), granulometric fraction (Roddaz et al. 2014) and depth (De Vos et al. 1996). In the second place, the variability in the uppermost and lowermost depths was evaluated and compared to the variability induced by duplicate samples on a regional scale. These two sources of variance were considered as relevant from a within-profile perspective. Finally, also on a regional scale and from an inter-profile perspective, a study of the main sources of variance which could be involved in the composition of the sediments was carried out. The sources of variance considered were land use (Ottesen et al. 1989; Macklin et al. 1994) and provenance (Cullers 2000; Roddaz et al. 2014).

\section{Study on a local scale}

Rivas profile, in the Manzanares River, was studied by considering the sources of variance that may influence the sediment within an isolated profile and also by dealing with the effects of grain size (granulometric fraction), depth (depth) and of the sampling site (duplicates). All of them were taken as the possible sources of variance affecting the composition. 
Fig. 2 Histograms of the raw data (left) and log-ratio-centred data (right) of several selected elements. The normal distribution after transformation should be appreciated
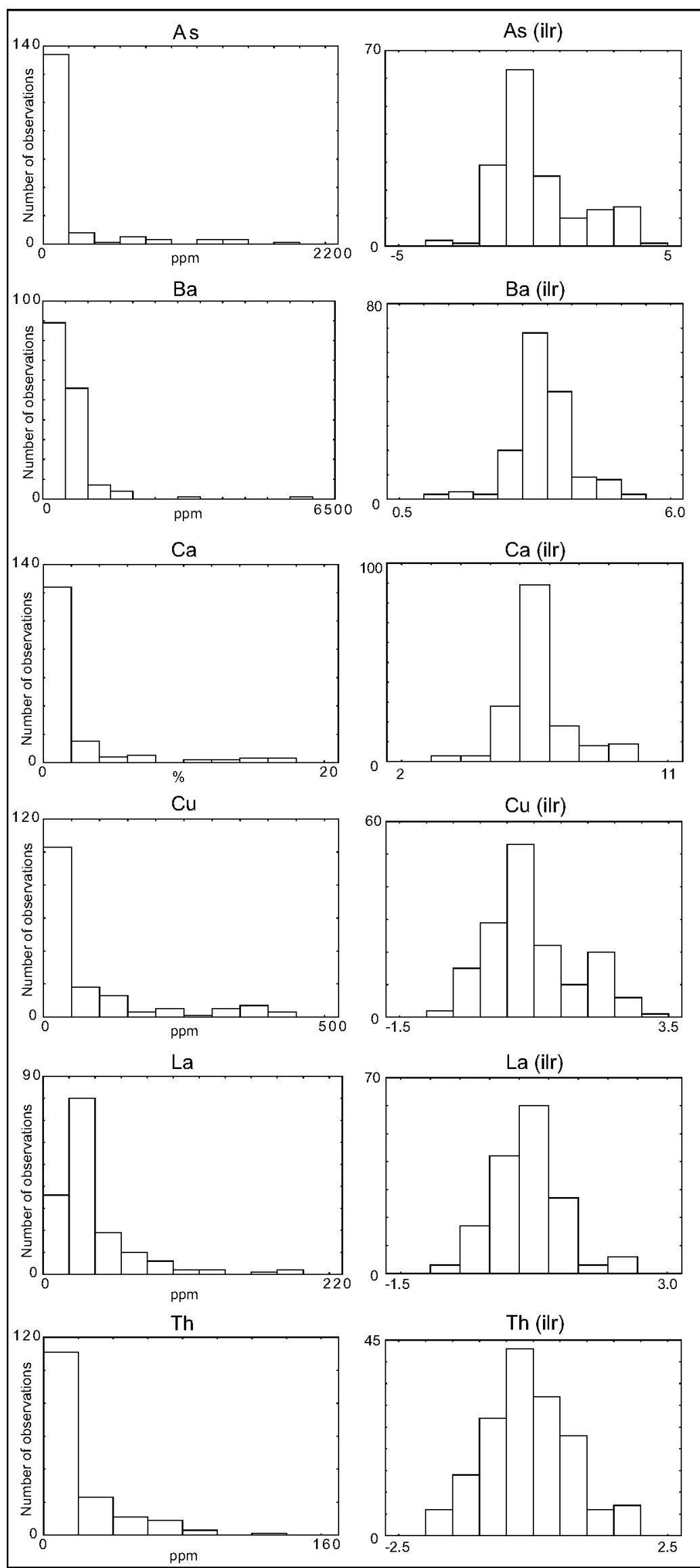
Finally, a fourth source of variance, which considers a comparison between depth within each pair of duplicates, was included in the analysis (Depth:Dupl).

A study of the complete profile was carried out in Adánez Sanjuán et al. (2014a). Dating techniques with ${ }^{14} \mathrm{C}$ showed a conventional radiocarbon age of $170 \pm 40$ years $\mathrm{BP}$ at $2.50 \mathrm{~m}$ depth and $90 \pm 40$ years BP, at $1.85 \mathrm{~m}$ depth. Chemical fractions may represent current potential to migration, but by means of a sequential extraction over trace metals in top and bottom samples, it was confirmed that post-depositional processes were negligible. In that study, it was demonstrated that in the sediments from Madrid Area (Manzanares, Guadarrama and Jarama Rivers), elements originating from urban and industrial activities were found preferentially in the most extractable fractions.

Original samples were taken at three depths $(0.00-0.30$, $0.60-0.95,2.00-2.40 \mathrm{~m}$ ), while a set of duplicate samples were taken at a distance of $2 \mathrm{~m}$ from the original ones, trying to sample the same layers. They were prepared (i.e. samples were sieved to six granulometric fractions, as explained above) and analysed by using the same procedures. The preparation was done by the same team and the samples were sent to the same laboratory as blind samples. Source of error in this case was the sample point as it was not the same and consequently, there is always the possibility that the samples do not represent the same sediment facies and the same deposition age. In any case, extreme caution was used in order to prevent this from happening.

A tree diagram (Fig. 3) was performed (Ward's method and Euclidean distances) with the results of the contribution to variance for each source after the ANOVA analysis (Table 1). The elements were grouped as follows:

Cluster 1 is formed by the elements with high significance levels in granulometric fractions. These elements are $\mathrm{Nd}$, Th, $\mathrm{La}, \mathrm{Sm}, \mathrm{Ce}, \mathrm{Yb}, \mathrm{Y}, \mathrm{Ly}, \mathrm{Rb}, \mathrm{Na}, \mathrm{Li}, \mathrm{Tl}, \mathrm{K}$ and Al. $P$ value is $<0.001$ for all these elements.
It is not possible with ANOVA to differentiate the grain size preference in these elements, but looking at the raw contents, some basic features can be detected. The majority of elements grouped in this cluster are rare earth elements. The contents of REE in fluvial sediments reflect the bedrock where they come from (Piper and Bau, 2013). As it is shown in Fig. 4 with raw, chondrite normalised and NASC (North American shale composite) normalised data, the distribution of REE is similar to the sedimentary rock general trend in the three plots. There is also a Eu depletion, which Taylor and McLennan (1985) describe as a consequence of the fractionation within the continental crust. In particular, during the fractional crystallisation of plagioclase, $\mathrm{Eu}^{2+}$ can be substituted for $\mathrm{Ca}^{2+}$ (Carmichael et al. 1974).

An example of the real composition of the samples is shown in Fig. 5, with the distribution of the elements $\mathrm{La}, \mathrm{Ce}, \mathrm{Pb}$ and $\mathrm{Au}$ according to the grain size for each of the studied samples. The distribution of the rest of REE in the granulometric fractions is quite uniform and similar to $\mathrm{La}$ and $\mathrm{Ce}$, having their highest contents in the fine fraction $<63 \mu \mathrm{m}$ (Fig. 4). Taylor and McLennan (1985) noticed the lower abundances of REEs in coarser-grained sedimentary rocks as compared with shales. The fine-grained fraction of sediments has lower contents of quartz and feldspar, but higher contents of clay minerals (an important carrier of the REEs). Elements grouped in this cluster are thus characterised by such distribution of their contents that there is a much wider variation among granulometric fractions than among depths.

Some potentially harmful elements also tend to be more concentrated in the $<63 \mu \mathrm{m}$ fraction, as it is shown in Fig. 5, with $\mathrm{Pb}$ and $\mathrm{Au}$. The difference with elements in cluster 1 is that potentially harmful elements present a wider variation of their contents with depth. In the case of $\mathrm{Pb}$, for example, this distribution with the grain size can be caused by a contribution of the k-feldspars present in the background geology.
Fig. 3 Tree diagram of the percentages of variance given by each of the sources

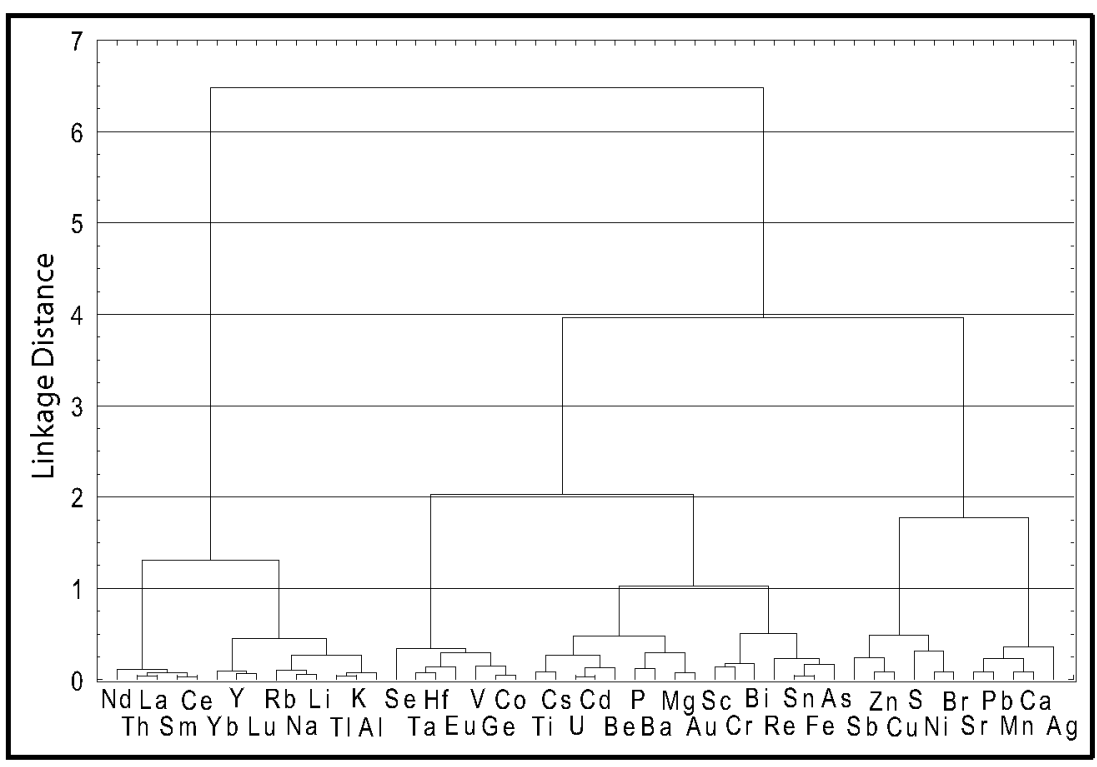


Table 1 Contribution to variance and significance levels of the studied elements in Rivas profile, for the selected sources of variance (grain size, depth, duplicates and depth:duplicates)

\begin{tabular}{|c|c|c|c|c|c|c|c|c|c|c|}
\hline & & \multicolumn{2}{|c|}{ Grain size } & \multicolumn{2}{|l|}{ Depth } & \multicolumn{2}{|c|}{ Duplicates } & \multicolumn{2}{|c|}{ Depth:Dupl } & \multirow{2}{*}{$\begin{array}{l}\text { Residuals } \\
\% \text { var }\end{array}$} \\
\hline & & $\%$ var & $p$ value & $\%$ var & $p$ value & $\%$ var & $p$ value & $\%$ var & $p$ value & \\
\hline \multirow[t]{14}{*}{ CLUSTER 1} & $\mathrm{Nd}$ & $76 \%$ & $* * *$ & $5 \%$ & $*$ & $2 \%$ & $*$ & $2 \%$ & & $15 \%$ \\
\hline & $\mathrm{Th}$ & $76 \%$ & $* * *$ & $9 \%$ & $* * *$ & $3 \%$ & $* *$ & $3 \%$ & $* *$ & $9 \%$ \\
\hline & $\mathrm{La}$ & $79 \%$ & $* * *$ & $7 \%$ & $* * *$ & $4 \%$ & $* * *$ & $3 \%$ & $* *$ & $7 \%$ \\
\hline & $\mathrm{Sm}$ & $80 \%$ & $* * *$ & $4 \%$ & $* *$ & $3 \%$ & $* * *$ & $5 \%$ & $* * *$ & $8 \%$ \\
\hline & $\mathrm{Ce}$ & $82 \%$ & $* * *$ & $3 \%$ & $* *$ & $5 \%$ & $* * *$ & $3 \%$ & $* *$ & $7 \%$ \\
\hline & $\mathrm{Yb}$ & $53 \%$ & $* * *$ & $2 \%$ & & $4 \%$ & & $8 \%$ & $*$ & $34 \%$ \\
\hline & $\mathrm{Y}$ & $53 \%$ & $* * *$ & $7 \%$ & & $8 \%$ & $* *$ & $4 \%$ & & $28 \%$ \\
\hline & $\mathrm{Lu}$ & $48 \%$ & $* * *$ & $8 \%$ & & $6 \%$ & $*$ & $8 \%$ & $*$ & $30 \%$ \\
\hline & $\mathrm{Rb}$ & $54 \%$ & $* * *$ & $23 \%$ & $* * *$ & $0 \%$ & & $4 \%$ & & $19 \%$ \\
\hline & $\mathrm{Na}$ & $54 \%$ & $* * *$ & $16 \%$ & $* *$ & $1 \%$ & & $3 \%$ & & $27 \%$ \\
\hline & $\mathrm{Li}$ & $52 \%$ & $* * *$ & $19 \%$ & $* * *$ & $4 \%$ & $*$ & $1 \%$ & & $24 \%$ \\
\hline & $\mathrm{Tl}$ & $65 \%$ & $* * *$ & $12 \%$ & $* *$ & $0 \%$ & & $2 \%$ & & $20 \%$ \\
\hline & $\mathrm{K}$ & $64 \%$ & $* * *$ & $15 \%$ & $* * *$ & $0 \%$ & & $3 \%$ & & $18 \%$ \\
\hline & $\mathrm{Al}$ & $63 \%$ & $* * *$ & $11 \%$ & $* *$ & $0 \%$ & & $1 \%$ & & $25 \%$ \\
\hline \multirow[t]{7}{*}{ CLUSTER 2} & $\mathrm{Se}$ & $7 \%$ & & $4 \%$ & & $2 \%$ & & $0 \%$ & & $87 \%$ \\
\hline & $\mathrm{Ta}$ & $26 \%$ & & $2 \%$ & & $3 \%$ & & $1 \%$ & & $67 \%$ \\
\hline & Hf & $23 \%$ & & $4 \%$ & & $0 \%$ & & $7 \%$ & & $66 \%$ \\
\hline & $\mathrm{Eu}$ & $16 \%$ & & $2 \%$ & & $2 \%$ & & $6 \%$ & & $74 \%$ \\
\hline & $\mathrm{V}$ & $18 \%$ & & $18 \%$ & $*$ & $4 \%$ & & $1 \%$ & & $59 \%$ \\
\hline & $\mathrm{Ge}$ & $13 \%$ & & $11 \%$ & & $1 \%$ & & $9 \%$ & & $66 \%$ \\
\hline & $\mathrm{Co}$ & $13 \%$ & & $14 \%$ & & $3 \%$ & & $7 \%$ & & $64 \%$ \\
\hline \multirow[t]{16}{*}{ CLUSTER 3} & Ti & $29 \%$ & $* * *$ & $37 \%$ & $* * *$ & $2 \%$ & & $7 \%$ & $*$ & $25 \%$ \\
\hline & $\mathrm{Cs}$ & $37 \%$ & $* * *$ & $36 \%$ & $* * *$ & $0 \%$ & & $4 \%$ & & $23 \%$ \\
\hline & $\mathrm{U}$ & $35 \%$ & $* * *$ & $28 \%$ & $* * *$ & $3 \%$ & & $1 \%$ & & $33 \%$ \\
\hline & $\mathrm{Cd}$ & $33 \%$ & $* * *$ & $28 \%$ & $* * *$ & $4 \%$ & $*$ & $3 \%$ & & $32 \%$ \\
\hline & $\mathrm{Be}$ & $41 \%$ & $* * *$ & $23 \%$ & $* *$ & $0 \%$ & & $0 \%$ & & $36 \%$ \\
\hline & $P$ & $25 \%$ & $*$ & $18 \%$ & $*$ & $5 \%$ & & $7 \%$ & & $45 \%$ \\
\hline & $\mathrm{Ba}$ & $33 \%$ & $* *$ & $12 \%$ & & $0 \%$ & & $4 \%$ & & $51 \%$ \\
\hline & $\mathrm{Mg}$ & $31 \%$ & $* * *$ & $23 \%$ & $* * *$ & $0 \%$ & & $13 \%$ & $* *$ & $32 \%$ \\
\hline & $\mathrm{Au}$ & $30 \%$ & $* * *$ & $17 \%$ & $* *$ & $2 \%$ & & $17 \%$ & $* *$ & $33 \%$ \\
\hline & $\mathrm{Sc}$ & $18 \%$ & $*$ & $37 \%$ & $* * *$ & $10 \%$ & $* *$ & $2 \%$ & & $33 \%$ \\
\hline & $\mathrm{Cr}$ & $14 \%$ & & $27 \%$ & $* * *$ & $11 \%$ & $* *$ & $10 \%$ & $*$ & $38 \%$ \\
\hline & $\mathrm{Bi}$ & $17 \%$ & $*$ & $39 \%$ & $* * *$ & $0 \%$ & & $12 \%$ & $* *$ & $31 \%$ \\
\hline & $\operatorname{Re}$ & $6 \%$ & & $31 \%$ & $* *$ & $0 \%$ & & $0 \%$ & & $63 \%$ \\
\hline & $\mathrm{Sn}$ & $6 \%$ & & $21 \%$ & $*$ & $8 \%$ & $*$ & $11 \%$ & $*$ & $54 \%$ \\
\hline & $\mathrm{Fe}$ & $7 \%$ & & $22 \%$ & $* *$ & $10 \%$ & $*$ & $11 \%$ & $*$ & $50 \%$ \\
\hline & As & $14 \%$ & & $28 \%$ & $* *$ & $4 \%$ & & $5 \%$ & & $49 \%$ \\
\hline \multirow[t]{11}{*}{ CLUSTER 4} & $\mathrm{Sb}$ & $1 \%$ & & $64 \%$ & $* * *$ & $8 \%$ & $* * *$ & $20 \%$ & $* * *$ & $8 \%$ \\
\hline & $\mathrm{Zn}$ & $3 \%$ & & $84 \%$ & $* * *$ & $2 \%$ & $* * *$ & $9 \%$ & $* * *$ & $3 \%$ \\
\hline & $\mathrm{Cu}$ & $2 \%$ & $* *$ & $78 \%$ & $* * *$ & $2 \%$ & $* * *$ & $15 \%$ & $* * *$ & $3 \%$ \\
\hline & $\mathrm{S}$ & $9 \%$ & $*$ & $50 \%$ & $* * *$ & $19 \%$ & $* * *$ & $5 \%$ & $*$ & $17 \%$ \\
\hline & $\mathrm{Ni}$ & $3 \%$ & & $69 \%$ & $* * *$ & $1 \%$ & & $7 \%$ & $* *$ & $20 \%$ \\
\hline & $\mathrm{Br}$ & $3 \%$ & & $63 \%$ & $* * *$ & $1 \%$ & & $6 \%$ & $*$ & $27 \%$ \\
\hline & $\mathrm{Sr}$ & $14 \%$ & $* *$ & $38 \%$ & $* * *$ & $0 \%$ & & $31 \%$ & $* * *$ & $17 \%$ \\
\hline & $\mathrm{Pb}$ & $17 \%$ & & $34 \%$ & $* * *$ & $5 \%$ & $* * *$ & $32 \%$ & $* * *$ & $12 \%$ \\
\hline & $\mathrm{Mn}$ & $9 \%$ & $*$ & $32 \%$ & $* * *$ & $0 \%$ & & $41 \%$ & $* * *$ & $18 \%$ \\
\hline & $\mathrm{Ca}$ & $3 \%$ & & $31 \%$ & $* * *$ & $6 \%$ & $* *$ & $43 \%$ & $* * *$ & $17 \%$ \\
\hline & $\mathrm{Ag}$ & $1 \%$ & & $17 \%$ & $* *$ & $11 \%$ & $* *$ & $38 \%$ & $* * *$ & $32 \%$ \\
\hline
\end{tabular}

Signification codes: $0 * * * 0.001 * * 0.01 * 0.1$ 


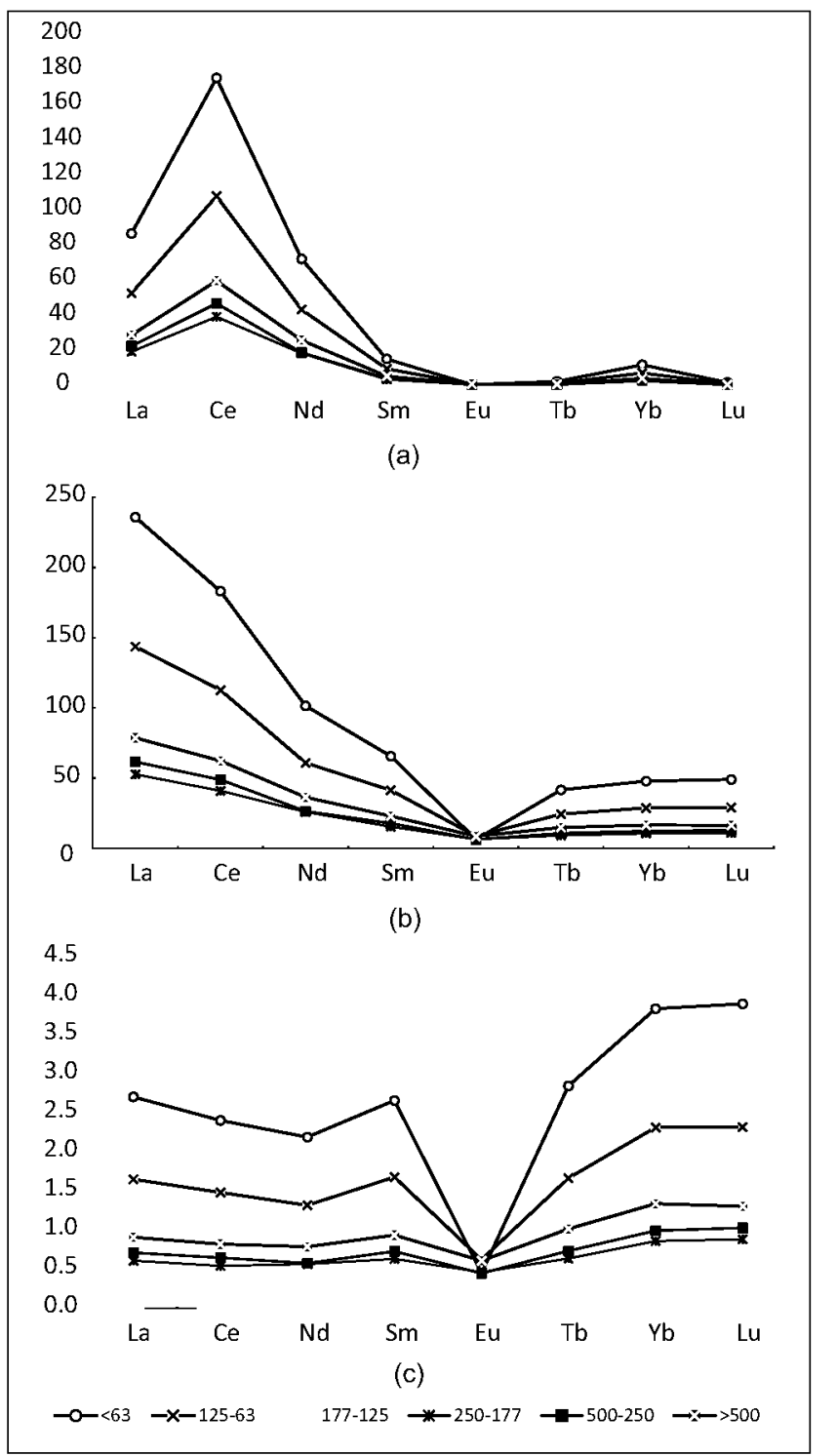

Fig. 4 REE contents of Rivas profile samples in the studied granulometric fractions $(\mu \mathrm{m})$. a Raw data $(\mathrm{ppm})$. b Chondrite normalised. c NASC normalised (after Taylor and McLennan (1985)

Cluster 2 is formed by the elements $\mathrm{Se}, \mathrm{Ta}, \mathrm{Hf}, \mathrm{Eu}, \mathrm{V}, \mathrm{Ge}$ and $\mathrm{Co}$. They present low significance levels in all the sources of variance and are characterised by a higher contribution to variance in the residual source. This source, which is created by the ANOVA analysis, indicates that the wider variation of these elements is produced by sources that have not been taken into account in this study.

Cluster 3 is formed by the elements Ti, Cs, U, Cd, Be, P, $\mathrm{Ba}, \mathrm{Mg}, \mathrm{Au}, \mathrm{Sc}, \mathrm{Cr}, \mathrm{Bi}, \mathrm{Re}, \mathrm{Sn}, \mathrm{Fe}$ and As. These elements show higher significance levels, as well as a higher contribution to variance, in the depth source and some of them also show a high significance in the granulometric fractions.

Cluster 4 is formed by the elements $\mathrm{Sb}, \mathrm{Zn}, \mathrm{Cu}, \mathrm{S}, \mathrm{Ni}, \mathrm{Br}, \mathrm{Sr}$, $\mathrm{Pb}, \mathrm{Mn}, \mathrm{Ca}$ and $\mathrm{Ag}$, which display the highest contribution to variance in the source called depth $(17-84 \%)$, where there is a high significance too. Duplicates have a lower signification and its contribution to variance is much lower than depth's (019\%). The variance source called Depth:Dupl represents the combination of these two sources. The aim is to know if the variance of the duplicates in the uppermost depth is significantly higher than in the duplicates in the lowermost depth or vice versa. The range of the contribution to variance of this combination is 6 to $43 \%$ (Table 1). Thus, the variances of the duplicated samples change significantly when depth changes.

The differences in element contents among granulometric fractions or between original and duplicate samples are low compared to the differences between depths. Most of the elements that are now grouped in cluster 4 were presented in Adánez Sanjuán et al. (2014a) as supplied by the anthropogenic activity in the city of Madrid. Their contents vary greatly from the uppermost to the lowermost samples. In Adánez Sanjuán et al. (2014a), these elements were associated with urban traffic (leaded petrol, tyre wear, brakes or corrosion expel elements like $\mathrm{Pb}, \mathrm{Mn}, \mathrm{Br}, \mathrm{Zn}$ or $\mathrm{Cu}$ ), construction cement ( $\mathrm{Ca}$ ), sewage sludge $(\mathrm{Ag}, \mathrm{Cr}$ ) or waste incineration $(\mathrm{Sb}, \mathrm{Zn})$. Thus, the major source of variance in these "anthropogenic" elements is depth, while the impact of granulometric fraction is scarce.

\section{Study on a regional scale: within-basin perspective}

The aim of this analysis is to study the sources of variance which depend only on the profile itself. To perform the analysis, 10 of the studied profiles were considered (Besaya, Besós, Adaja, Zapardiel, Manzanares-Rivas, Guadarrama, Jarama, Bonhabal, Valdeazogues and Guadajoz). With this purpose, two profile intrinsic sources of variance were taken into account. The first source, called duplicates, represents the variability between original and duplicate samples.

Duplicate samples were taken by a second team, who sampled systematically the uppermost and lowermost $20 \mathrm{~cm}$ of each profile, at the same coordinates as the original ones and following the instructions of the Spanish Geochemical Atlas (Locutura et al. 2012). Different teams did the preparation for the analysis (drying, sieving and grinding) but the chemical analysis were carried out in the same laboratories (Actlabs, Canada). Sources of error in this case were sampling criteria (depending on the team) and sampling preparation. Variability of this source could be interpreted as the reproducibility. The second source of variance is called depth, and it is the variability between uppermost and lowermost samples in the vertical profiles where the horizontal sediment layers are recognised.

The results of the analysis of variance show that the two sources of variance have in this case, very low significance levels, with $p$ values higher than 0.1 for most of the elements (Table 2). Thus, variances inside groups are similar to variances between groups.

Comparing the two sources of variance (lower than $15 \%$ for both), there is a slightly higher significance in the duplicates 
Fig. 5 Variation of $\mathrm{La}, \mathrm{Ce}, \mathrm{Pb}$ and Au contents with grain size $(\mu \mathrm{m})$ in Rivas profile (Manzanares River)

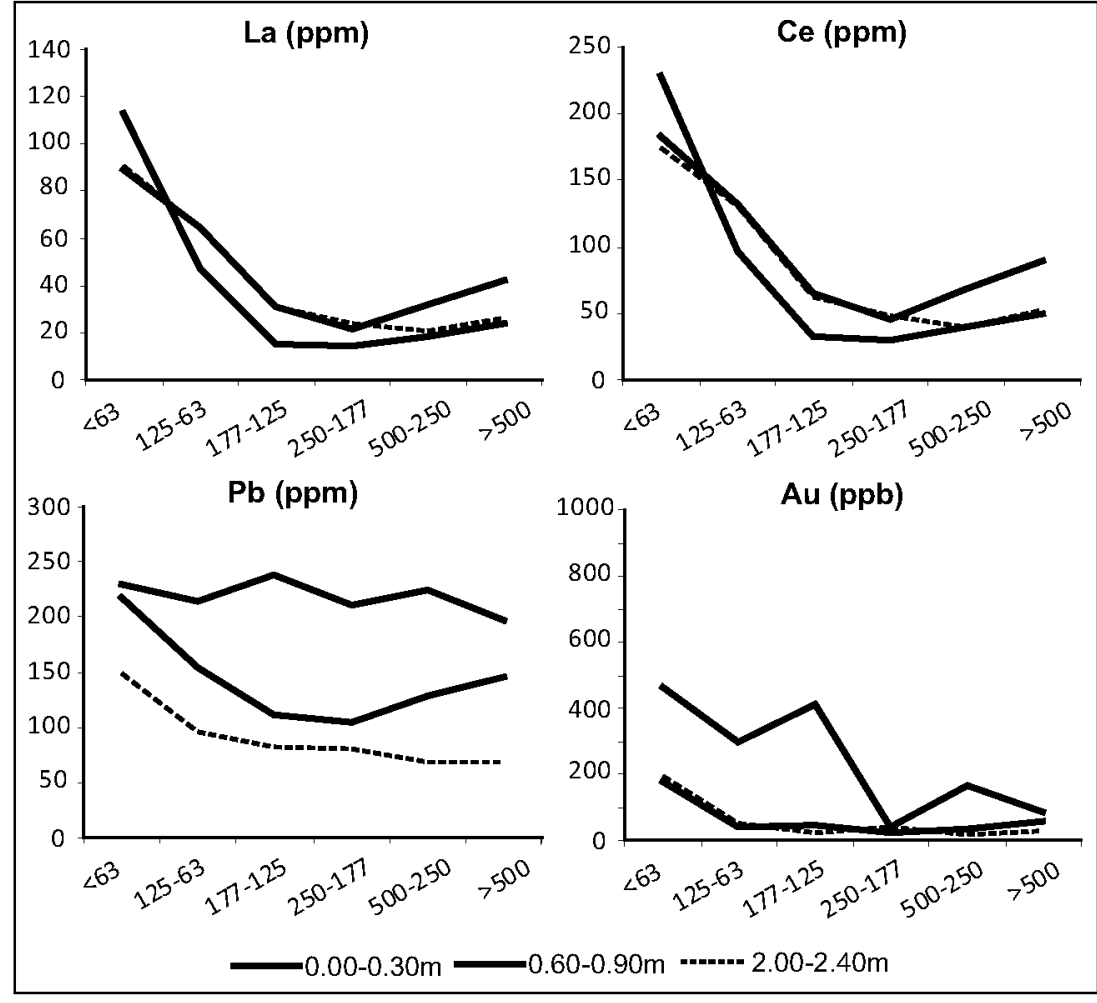

source than in the depth source. Only Ba, Na, P, Rb and Ta have a significance lower than 0.1 , but none of the elements has $p$ values lower than 0.01 . On the contrary, the depth source shows $p$ values higher than 0.1 in all the analysed elements.

The contribution to variance is also very low in the duplicates and depth sources, whereas the contribution to variance of the residual source is very high. Therefore, the variability between original and duplicate samples is low, as well as the variability between uppermost and lowermost samples. On a regional scale, these variations are not significant although the content variation is high for some particular profiles; it can be mentioned the Besós profile, where for example, $\mathrm{Cr}$ varies from $82 \mathrm{ppm}$ in the uppermost part to $520 \mathrm{ppm}$ in the lowermost part of the original samples. But it varies from 82 to $92 \mathrm{ppm}$ in the duplicate one. Therefore, the difference between original (92 ppm) and duplicate (520 ppm) samples in the lowermost part is almost as high as the difference between uppermost and lowermost samples in the original samples. Other elements as $\mathrm{Ni}, \mathrm{Pb}, \mathrm{Hg}, \mathrm{Zn}$ or $\mathrm{Cu}$ are in the same conditions. This is due to the fact that in Besós profile, the interval corresponding to the lowermost original sample included a 1-cm layer with different physical characteristics (colour, grain size). Once the original and duplicate samples were analysed, the results showed very high metal contents in the original one (Adánez 2012). In the duplicate sample, this level was not sampled, causing a great difference of contents. A similar situation was detected in Besaya profile (Cd, Fe, Pb or Zn) (Adánez 2012). Here, there is an evident case of sampling error, which can cause very different results (in this case due to an anomalous layer). But ilr transformation normalises the results by taking the mean value of each profile, so that this anomalous value is softened.

The fact that duplicates and depth are not significant sources of variance on a regional scale, may be due to the existence of other unknown sources of variance which cause a decrease in the significance of the inner variance for the studied profiles. Therefore, in the regional scale, regardless of possible anomalies and/or errors, within-basin variations are not significant.

\section{Study on a regional scale: inter-basin perspective}

To detect and assess the significance of possible sources of variance from an inter-profile perspective, the profiles were classified into two groups: land use and provenance.

Regarding the land use source, profiles were classified according to the most important anthropogenic activity developed in the basin. The most representative anthropogenic activities are mining, urban-industrial, agriculture and pristine (uninhabited areas or with very low population).

To classify the profiles according to the provenance source, some particular element ratios were used, in order to recognise the main lithologies where sediments come from. Cullers (2000) stated that $\mathrm{La}$ and Th were more concentrated in silicic than in basic igneous rocks, whereas, $\mathrm{Co}, \mathrm{Sc}$ and $\mathrm{Cr}$ were more 
Table 2 Contribution to variance and significance levels of the studied elements for the selected sources of variance (depth and duplicates)

\begin{tabular}{|c|c|c|c|c|c|}
\hline & \multicolumn{2}{|l|}{ Depth } & \multicolumn{2}{|c|}{ Duplicates } & \multirow{2}{*}{$\begin{array}{l}\text { Residual } \\
\% \text { var }\end{array}$} \\
\hline & $\%$ var & $p$-value & $\%$ var & $p$-value & \\
\hline $\mathrm{Ag}$ & $0 \%$ & & $0 \%$ & & $100 \%$ \\
\hline $\mathrm{Al}$ & $1 \%$ & & $2 \%$ & & $98 \%$ \\
\hline As & $0 \%$ & & $2 \%$ & & $98 \%$ \\
\hline $\mathrm{Au}$ & $1 \%$ & & $3 \%$ & & $96 \%$ \\
\hline $\mathrm{Ba}$ & $0 \%$ & & $12 \%$ & $*$ & $88 \%$ \\
\hline $\mathrm{Be}$ & $0 \%$ & & $5 \%$ & & $95 \%$ \\
\hline $\mathrm{Bi}$ & $1 \%$ & & $0 \%$ & & $99 \%$ \\
\hline $\mathrm{Br}$ & $0 \%$ & & $0 \%$ & & $100 \%$ \\
\hline $\mathrm{Ca}$ & $0 \%$ & & $0 \%$ & & $99 \%$ \\
\hline $\mathrm{Cd}$ & $0 \%$ & & $2 \%$ & & $98 \%$ \\
\hline $\mathrm{Ce}$ & $1 \%$ & & $4 \%$ & & $95 \%$ \\
\hline $\mathrm{Co}$ & $0 \%$ & & $1 \%$ & & $99 \%$ \\
\hline $\mathrm{Cr}$ & $0 \%$ & & $0 \%$ & & $100 \%$ \\
\hline $\mathrm{Cs}$ & $0 \%$ & & $3 \%$ & & $97 \%$ \\
\hline $\mathrm{Cu}$ & $0 \%$ & & $4 \%$ & & $96 \%$ \\
\hline $\mathrm{Eu}$ & $1 \%$ & & $5 \%$ & & $94 \%$ \\
\hline $\mathrm{Fe}$ & $1 \%$ & & $0 \%$ & & $99 \%$ \\
\hline $\mathrm{Ge}$ & $4 \%$ & & $1 \%$ & & $95 \%$ \\
\hline Hf & $4 \%$ & & $8 \%$ & & $88 \%$ \\
\hline $\mathrm{K}$ & $1 \%$ & & $7 \%$ & & $92 \%$ \\
\hline $\mathrm{La}$ & $2 \%$ & & $3 \%$ & & $95 \%$ \\
\hline $\mathrm{Li}$ & $0 \%$ & & $4 \%$ & & $96 \%$ \\
\hline $\mathrm{Lu}$ & $0 \%$ & & $0 \%$ & & $100 \%$ \\
\hline $\mathrm{Mg}$ & $1 \%$ & & $4 \%$ & & $96 \%$ \\
\hline $\mathrm{Mn}$ & $0 \%$ & & $2 \%$ & & $98 \%$ \\
\hline $\mathrm{Na}$ & $0 \%$ & & $6 \%$ & $*$ & $94 \%$ \\
\hline $\mathrm{Nd}$ & $1 \%$ & & $3 \%$ & & $96 \%$ \\
\hline $\mathrm{Ni}$ & $0 \%$ & & $0 \%$ & & $100 \%$ \\
\hline $\mathrm{P}$ & $0 \%$ & & $11 \%$ & $*$ & $89 \%$ \\
\hline $\mathrm{Pb}$ & $0 \%$ & & $0 \%$ & & $100 \%$ \\
\hline $\mathrm{Rb}$ & $0 \%$ & & $10 \%$ & $*$ & $90 \%$ \\
\hline $\operatorname{Re}$ & $1 \%$ & & $2 \%$ & & $97 \%$ \\
\hline S & $0 \%$ & & $2 \%$ & & $98 \%$ \\
\hline $\mathrm{Sb}$ & $0 \%$ & & $0 \%$ & & $99 \%$ \\
\hline $\mathrm{Sc}$ & $0 \%$ & & $0 \%$ & & $100 \%$ \\
\hline $\mathrm{Se}$ & $1 \%$ & & $4 \%$ & & $95 \%$ \\
\hline $\mathrm{Sm}$ & $1 \%$ & & $3 \%$ & & $96 \%$ \\
\hline $\mathrm{Sn}$ & $1 \%$ & & $3 \%$ & & $96 \%$ \\
\hline $\mathrm{Sr}$ & $1 \%$ & & $1 \%$ & & $99 \%$ \\
\hline $\mathrm{Ta}$ & $3 \%$ & & $8 \%$ & $*$ & $88 \%$ \\
\hline $\mathrm{Th}$ & $0 \%$ & & $3 \%$ & & $97 \%$ \\
\hline $\mathrm{Ti}$ & $0 \%$ & & $0 \%$ & & $100 \%$ \\
\hline $\mathrm{Tl}$ & $0 \%$ & & $0 \%$ & & $100 \%$ \\
\hline $\mathrm{U}$ & $0 \%$ & & $0 \%$ & & $100 \%$ \\
\hline $\mathrm{V}$ & $0 \%$ & & $1 \%$ & & $99 \%$ \\
\hline $\mathrm{Y}$ & $1 \%$ & & $2 \%$ & & $98 \%$ \\
\hline $\mathrm{Yb}$ & $0 \%$ & & $0 \%$ & & $100 \%$ \\
\hline $\mathrm{Zn}$ & $0 \%$ & & $0 \%$ & & $100 \%$ \\
\hline
\end{tabular}

Signification codes: 0 “****» 0.001 “**" “0.01“**" $0.1 “ "$ 


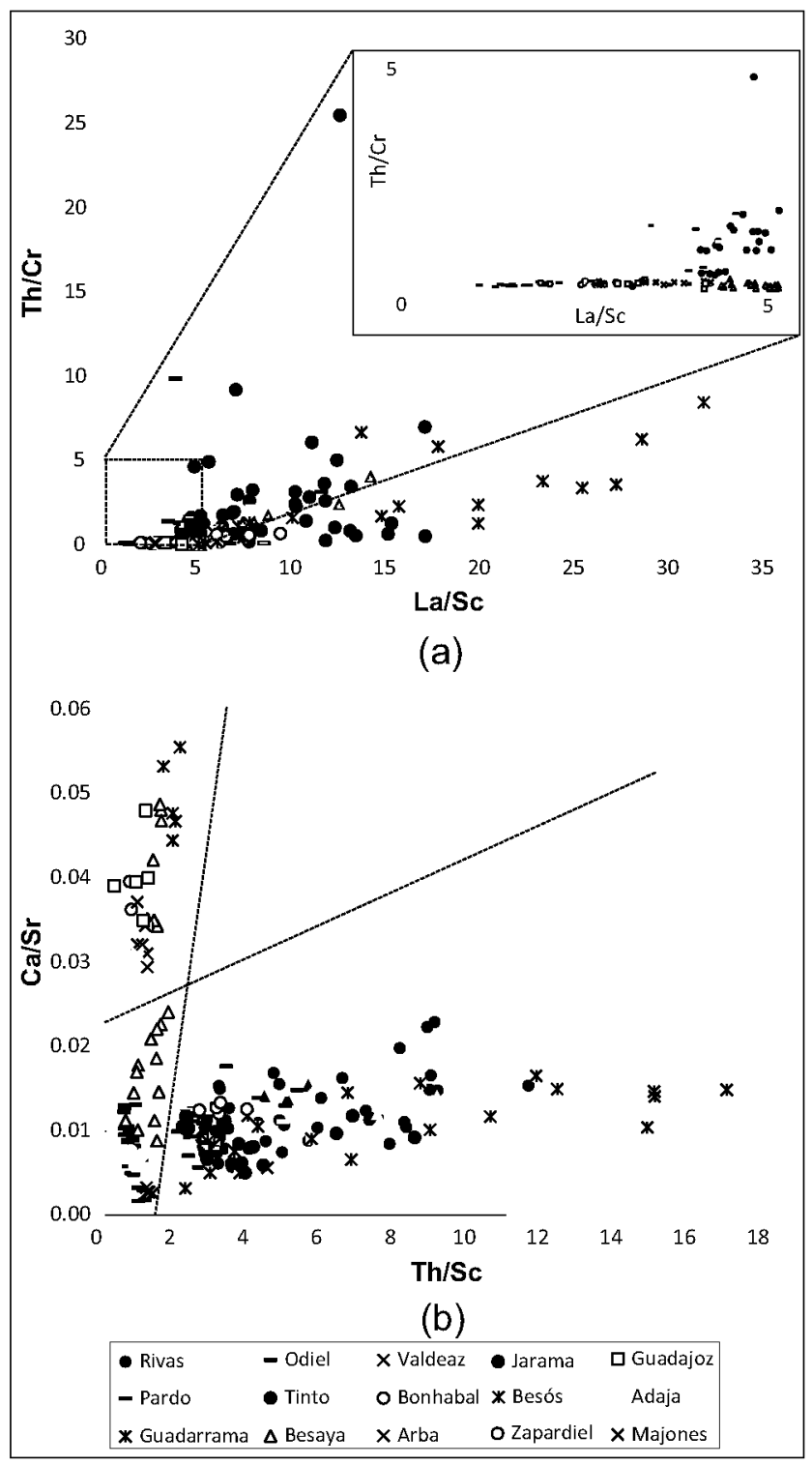

Fig. 6 Biplot diagrams of a $\mathrm{La} / \mathrm{Sc}$ vs. $\mathrm{Th} / \mathrm{Cr}$ and $\mathbf{b} \mathrm{Th} / \mathrm{Sc}$ vs. $\mathrm{Ca} / \mathrm{Sr}$. Symbols correspond to each of the studied profiles

concentrated in basic than silicic igneous rocks. To discriminate between silicic rocks and basic source, $\mathrm{La} / \mathrm{Sc}, \mathrm{Th} / \mathrm{Sc}, \mathrm{La} / \mathrm{Co}$, $\mathrm{Th} / \mathrm{Co}, \mathrm{Th} / \mathrm{Cr}$ were studied according to Cullers (2000) and Roddaz et al. (2014). These authors suggest some particular values for these ratios to classify the sediment origin. In this case, these values were modified in order to make a coherent classification, since the element ranges are wider and the sources of sediments are highly dissimilar.

Using the $\mathrm{Th} / \mathrm{Sc}, \mathrm{Th} / \mathrm{Cr}$ and $\mathrm{La} / \mathrm{Sc}$ ratios, two different behaviours were detected in the samples. The most silicic samples are Rivas, Guadarrama, Pardo, Jarama, Adaja and Zapardiel, which show $\mathrm{Th} / \mathrm{Sc}>1.5, \mathrm{Th} / \mathrm{Cr}>0.3$ and $\mathrm{La} / \mathrm{Sc}>5$ (Fig. 6a, b).

Since not all the rest of the samples have a basic origin, a $\mathrm{Ca} / \mathrm{Sr}$ ratio was calculated in order to discriminate between basic samples and carbonate rock-derived samples (with a
Table 3 Classification of the samples according to the land use of the basin and the provenance

\begin{tabular}{lll}
\hline Profile & Land Use & Provenance \\
\hline Pardo & Urban & Silicic \\
Rivas & Urban & Silicic \\
Guadarrama & Urban & Silicic \\
Jarama & Agriculture & Silicic \\
Odiel & Mining & Basic \\
Tinto & Mining & Basic \\
Besaya & Urban & Basic \\
Besós & Urban & Carbonatic \\
Bonhabal & Mining & Carbonatic \\
Valdeazogues & Mining & Basic \\
Arba & Agriculture & Carbonatic \\
Zapardiel & Agriculture & Silicic \\
Guadajoz & Agriculture & Carbonatic \\
Adaja & Pristine & Silicic \\
Majones & Pristine & Carbonatic \\
\hline
\end{tabular}

high proportion of carbonatic material). In Fig. 6b, there is a clear distinction assuming that sediment samples with $\mathrm{Ca} / \mathrm{Sr}$ ratio higher than 0.03 are mainly formed by carbonate lithologies (e.g. limestones, dolostones or marls). By means of these element ratios, the profiles can be classified according to the composition of the sediment matrix. Besós, Guadajoz, Bonhabal, Arba and Majones are interpreted as carbonate rock-derived, whereas the Odiel, Tinto, Valdeazogues and Besaya are regarded as basic (Table 3).

The analysis of variance was carried out considering three sources of variance: land use, provenance and a third source called land use: provenance. This source represents the interaction between these two sources of variance through which it can be appreciated the variation of the land use source within each of the selected provenances, in the same way as the Depth:Dupl source, studied in the previous section, does. Regarding the significance levels, the results of the ANOVA analysis (Table 4) show a high significance ( $p$ value $>0.001$ ) in land use and provenance for most of the elements. As well, a high significance in the land use: provenance source is found in $\mathrm{Zn}, \mathrm{Bi}, \mathrm{Cd}, \mathrm{Mg}$ and $\mathrm{Br}$, meaning that these elements have a high variation in the different land uses considering a specific lithology.

On the other hand, regarding the contribution to variance, each of the studied sources has specific characteristics:

- The land use: provenance source is the one with the least contribution to variance. None of the element contribution exceeds $30 \%$.

- There are several elements with a high contribution in land use ( $>40 \%)$. The highest is given by the elements $\mathrm{Sr}, \mathrm{Sb}$, $\mathrm{Fe}, \mathrm{Cu}, \mathrm{Cs}$, As and $\mathrm{Sc}$. There are also some elements with a great difference of contribution to the variance between the 
Table 4 Contribution to the variance (\% var) and significance levels ( $p$ value) of the studied elements for the selected sources of variance (land use, provenance and landuse:provenance)

\begin{tabular}{|c|c|c|c|c|c|c|c|}
\hline & \multicolumn{2}{|c|}{ Land Use } & \multicolumn{2}{|c|}{ Provenance } & \multicolumn{2}{|c|}{ LandUse:Provenance } & \multirow[t]{2}{*}{ Residuals } \\
\hline & $\%$ var & $p$ value & $\%$ var & $p$ value & $\%$ var & $p$ value & \\
\hline $\mathrm{Ag}$ & $24 \%$ & $* * *$ & $6 \%$ & & $15 \%$ & $* *$ & $55 \%$ \\
\hline $\mathrm{Al}$ & $13 \%$ & $*$ & $28 \%$ & $* * *$ & $1 \%$ & & $57 \%$ \\
\hline As & $41 \%$ & $* * *$ & $28 \%$ & $* * *$ & $0 \%$ & & $30 \%$ \\
\hline $\mathrm{Au}$ & $23 \%$ & $* * *$ & $8 \%$ & $*$ & $11 \%$ & $*$ & $58 \%$ \\
\hline $\mathrm{Ba}$ & $1 \%$ & & $3 \%$ & & $1 \%$ & & $95 \%$ \\
\hline $\mathrm{Be}$ & $36 \%$ & $* * *$ & $26 \%$ & $* * *$ & $3 \%$ & & $35 \%$ \\
\hline $\mathrm{Bi}$ & $29 \%$ & $* * *$ & $1 \%$ & & $28 \%$ & $* * *$ & $42 \%$ \\
\hline $\mathrm{Br}$ & $28 \%$ & $* * *$ & $17 \%$ & $* * *$ & $17 \%$ & $* * *$ & $38 \%$ \\
\hline $\mathrm{Ca}$ & $36 \%$ & $* * *$ & $54 \%$ & $* * *$ & $3 \%$ & & $8 \%$ \\
\hline $\mathrm{Cd}$ & $26 \%$ & $* * *$ & $37 \%$ & $* * *$ & $14 \%$ & $* * *$ & $23 \%$ \\
\hline $\mathrm{Ce}$ & $30 \%$ & $* * *$ & $33 \%$ & $* * *$ & $5 \%$ & & $32 \%$ \\
\hline Co & $12 \%$ & $*$ & $24 \%$ & $* * *$ & $11 \%$ & $*$ & $53 \%$ \\
\hline $\mathrm{Cr}$ & $14 \%$ & **** & $39 \%$ & $* * *$ & $12 \%$ & *** & $35 \%$ \\
\hline $\mathrm{Cs}$ & $42 \%$ & $* * *$ & $7 \%$ & $*$ & $5 \%$ & & $47 \%$ \\
\hline $\mathrm{Cu}$ & $42 \%$ & **** & $7 \%$ & $*$ & $5 \%$ & & $45 \%$ \\
\hline $\mathrm{Eu}$ & $10 \%$ & & $7 \%$ & & $5 \%$ & & $79 \%$ \\
\hline $\mathrm{Fe}$ & $49 \%$ & *** & $24 \%$ & $* * *$ & $4 \%$ & $*$ & $23 \%$ \\
\hline $\mathrm{Ge}$ & $18 \%$ & $* *$ & $17 \%$ & $* *$ & $2 \%$ & & $63 \%$ \\
\hline $\mathrm{Hf}$ & $6 \%$ & & $2 \%$ & & $10 \%$ & & $82 \%$ \\
\hline $\mathrm{K}$ & $29 \%$ & $* * *$ & $24 \%$ & $* * *$ & $3 \%$ & & $43 \%$ \\
\hline $\mathrm{La}$ & $33 \%$ & $* * *$ & $29 \%$ & $* * *$ & $4 \%$ & & $33 \%$ \\
\hline $\mathrm{Li}$ & $37 \%$ & $* * *$ & $4 \%$ & & $1 \%$ & & $58 \%$ \\
\hline $\mathrm{Lu}$ & $17 \%$ & $* * *$ & $40 \%$ & $* * *$ & $11 \%$ & $* *$ & $32 \%$ \\
\hline $\mathrm{Mg}$ & $25 \%$ & $* * *$ & $40 \%$ & $* * *$ & $11 \%$ & $* * *$ & $25 \%$ \\
\hline $\mathrm{Mn}$ & $9 \%$ & & $20 \%$ & $* *$ & $8 \%$ & & $64 \%$ \\
\hline $\mathrm{Na}$ & $5 \%$ & $*$ & $70 \%$ & $* * *$ & $5 \%$ & $* *$ & $20 \%$ \\
\hline $\mathrm{Nd}$ & $26 \%$ & $* * *$ & $29 \%$ & $* * *$ & $4 \%$ & & $41 \%$ \\
\hline $\mathrm{Ni}$ & $13 \%$ & $* * *$ & $49 \%$ & $* * *$ & $5 \%$ & & $33 \%$ \\
\hline $\mathbf{P}$ & $26 \%$ & $* * *$ & $21 \%$ & $* * *$ & $11 \%$ & $* *$ & $42 \%$ \\
\hline $\mathrm{Pb}$ & $35 \%$ & $* * *$ & $42 \%$ & $* * *$ & $2 \%$ & & $21 \%$ \\
\hline $\mathrm{Rb}$ & $33 \%$ & $* * *$ & $18 \%$ & $* * *$ & $2 \%$ & & $47 \%$ \\
\hline $\mathrm{Re}$ & $6 \%$ & & $11 \%$ & $*$ & $1 \%$ & & $82 \%$ \\
\hline $\mathrm{S}$ & $19 \%$ & $* *$ & $22 \%$ & $* * *$ & $3 \%$ & & $56 \%$ \\
\hline $\mathrm{Sb}$ & $51 \%$ & *** & $18 \%$ & $* * *$ & $3 \%$ & & $28 \%$ \\
\hline $\mathrm{Sc}$ & $40 \%$ & *** & $18 \%$ & $* * *$ & $3 \%$ & & $39 \%$ \\
\hline $\mathrm{Se}$ & $11 \%$ & & $4 \%$ & & $5 \%$ & & $81 \%$ \\
\hline $\mathrm{Sm}$ & $30 \%$ & $* * *$ & $36 \%$ & $* * *$ & $4 \%$ & & $29 \%$ \\
\hline $\mathrm{Sn}$ & $24 \%$ & & $6 \%$ & & $6 \%$ & & $64 \%$ \\
\hline $\mathrm{Sr}$ & $54 \%$ & $* * *$ & $26 \%$ & $* * *$ & $4 \%$ & $*$ & $16 \%$ \\
\hline $\mathrm{Ta}$ & $7 \%$ & & $9 \%$ & $*$ & $20 \%$ & $* *$ & $65 \%$ \\
\hline $\mathrm{Th}$ & $31 \%$ & $* * *$ & $45 \%$ & $* * *$ & $3 \%$ & $*$ & $20 \%$ \\
\hline $\mathrm{T} i$ & $10 \%$ & & $2 \%$ & & $2 \%$ & & $87 \%$ \\
\hline $\mathrm{Tl}$ & $13 \%$ & $* *$ & $29 \%$ & $* * *$ & $12 \%$ & $*$ & $46 \%$ \\
\hline $\mathrm{U}$ & $38 \%$ & $* * *$ & $25 \%$ & $* * *$ & $5 \%$ & & $32 \%$ \\
\hline $\mathrm{V}$ & $34 \%$ & $* * *$ & $38 \%$ & $* * *$ & $1 \%$ & & $28 \%$ \\
\hline $\mathrm{Y}$ & $27 \%$ & $* * *$ & $29 \%$ & $* * *$ & $7 \%$ & $*$ & $38 \%$ \\
\hline $\mathrm{Yb}$ & $21 \%$ & $* * *$ & $39 \%$ & $* * *$ & $9 \%$ & $* *$ & $30 \%$ \\
\hline $\mathrm{Zn}$ & $15 \%$ & $* * *$ & $47 \%$ & $* * *$ & $29 \%$ & $* * *$ & $9 \%$ \\
\hline
\end{tabular}

Signification codes: $0 * * * 0.001 * * 0.01 * 0.1$ two main sources, being higher in land use. These are Cs, $\mathrm{Cu}$ and $\mathrm{Li}$. The contents of these elements can be widely variable, being concentrated in industrial and mining areas.

- In the provenance source, the elements that have a contribution to variance higher than a $40 \%$ are $\mathrm{Na}, \mathrm{Ca}, \mathrm{Ni}, \mathrm{Zn}$, Th, $\mathrm{Pb}, \mathrm{Mg}$ and $\mathrm{Lu}$. Sodium shows a greater contribution in this source than in land use. They are typical rock-forming elements. The fact that $\mathrm{Zn}$ and $\mathrm{Pb}$ seem to be more influenced by provenance may be caused by the fact that the profiles heavily influenced by mining activity were classified in the same group. In this analysis, REEs have a contribution to variance around $30 \%$ in both sources, while others such as $\mathrm{Ba}, \mathrm{Hf}, \mathrm{Se}, \mathrm{Ta}$ or Ti have a very low contribution.

\section{Conclusions}

Levee-overbank sediments were studied regarding the sources of variance that are usually taken into account upon a geochemical study. The sources of variance reviewed in this case study represent different degrees of impact in the determination of element contents. In other words, the relative influence of each source of variance in the analytical results was compared thus bringing to light the predominance of some of them.

On a regional scale, the highest variability (contribution to variance and signification) is detected in land use and provenance, indicating a similar influence of both sources in the composition of the sediments. Two groups of elements showed a major capacity to vary either with land use or with provenance. It is recommended therefore that $\mathrm{Na}, \mathrm{Ca}, \mathrm{Ni}, \mathrm{Zn}, \mathrm{Th}, \mathrm{Pb}, \mathrm{Mg}$ and $\mathrm{Lu}$ are included in studies where provenance, meaning the origin of sediment, has to be tracked. On the other hand, $\mathrm{Sr}, \mathrm{Sb}, \mathrm{Fe}, \mathrm{Cu}$, $\mathrm{Cs}, \mathrm{As}$ and $\mathrm{Sc}$ are recommended in studies were the land use, that is anthropogenic activity, is studied. There is also a third group of elements ( $\mathrm{Cs}, \mathrm{Cu}, \mathrm{Li}, \mathrm{Bi}, \mathrm{Ag}, \mathrm{Au}$ or $\mathrm{Sn}$ ), that having a much greater contribution to variance in land use, could be recommended in studies where provenance may mask the results.

On a local scale, in Rivas profile, which is affected by a heavy anthropogenic (urban-industrial) activity, heavy metals and other "anthropogenic" elements have been separated according to their most significant source of variance. Regarding the results, in environmental studies, depth is the most determining and relevant variable and must be carefully considered and examined. On the other hand, although grain size is of secondary importance, it plays an important role in other elements such as REE so it must neither be overlooked. Finally, depth and duplicates do not cause a significant variance if they are studied in a regional scale.

Thus, this study reflects the general known recommendation of a very careful sample selection in overbank sediments, which may be more or less decisive depending on the target elements and the objectives of the study. With the ilr 
transformation used for the ANOVA in compositional data, it has been possible to discriminate groups of elements depending on their most dominant source of variance.

Acknowledgements The authors thank the Geological Survey of Spain (IGME) for financing this research.

\section{References}

Adánez P (2012) La geoquímica de los sedimentos de llanuras de inundación como guía para la valoración ambiental en España. PhD Thesis. Universidad Politécnica de Madrid

Adánez Sanjuán P, Llamas Borrajo J, Locutura Rupérez J, García Cortés A (2014a) A geochemical study of overbank sediments in an urban area (Madrid, Spain). Environ Geochem Health 36(6):1129-1150

Adánez Sanjuán P, Llamas Borrajo J, Locutura Rupérez J, García CA (2014b) Estudio geoquímico de los sedimentos de llanura de inundación en la cuenca de los ríos Tinto y Odiel (Huelva). Bol Geol Min 125(4):585-599

Adánez Sanjuán P, Flem B, Llamas Borrajo J, Locutura Rupérez J, García Cortés A (2016) Application of lead isotopic methods to the study of the anthropogenic lead provenance in Spanish overbank floodplain deposits. Environ Geochem Health 38:449-468

Allen JRL (1965) A review of the origin and characteristics of recent alluvial sediments. Sedimentology 5:89-191

Barać N, Škrivanj S, Bukumirić Z, Živojinović D, Manojlović D, Barać M, Petrović R, Corac A (2016) Distribution and mobility of heavy elements in floodplain agricultural soils along the Ibar River (southern Serbia and northern Kosovo). Chemometric investigation of pollutant sources and ecological risk assessment. Environ Sci Pollut Res 23(9):9000-9011

Cánovas CR, Hubbard CG, Olías M, Nieto JM, Black S, Coleman ML (2008) Hydrochemical variations and contaminant load in the Río Tinto (Spain) during flood events. J Hydrol 350:25-40

Carmichael ISE, Turner FJ, Verhoogen J (1974) Igneous petrology. McGraw-Hill Book Company, New York

Cullers RL (2000) The geochemistry of shales, siltstones and sandstones of Pennsylvanian-Permian age, Colorado, USA: implications for provenance and metamorphic studies. Lithos 51:181-203

De Vos W, Ebbing J, Hindel R, Schalich J, Swennen R, Van Keer I (1996) Geochemical mapping on overbank sediments in the heavily industrialised border area of Belgium, Germany and the Netherlands. J Geochem Explor 56:91-104

Demetriades A, Volden T (1997) Reproducibility of overbank sediment sampling in Greece and Norway. J Geochem Explor 59:209-217

Filzmoser P, Hron K, Reimann C (2009) Univariate statistical analysis of environmental (compositional) data: problems and possibilities. Sci Total Environ 407:6100-6108

He Q, Walling DE (1997) Spatial variability of the particle size composition of overbank floodplain deposits. Water Air Soil Pollut 99(14):71-80

Higueras P, Oyarzun R, Biester H, Lillo J, Lorenzo S (2003) A first insight into mercury distribution and speciation in soils from the Almadén mining district, Spain. J Geochem Explor 80:95-104

Huertas E, Folch M, Salgot M, Gonzalvo I, Passarell C (2006) Constructed wetlands effluent for streamflow augmentation in the Besós River (Spain). Desalination 188:141-147
Langedal M (1996) Fluvial dispersion of particle-bound heavy metals: an evaluation of overbank sediments as sampling medium for regional geochemical mapping and environmental studies. PhD Thesis. Norges Teknisk-Naturvitenskapelige Universtet

Leistel JM, Marcoux E, Thiéblemont D, Quesada C, Sánchez A, Almodóvar GR, Pascual E, Sáez R (1998) The volcanic-hosted massive sulphide deposits of the Iberian Pyrite Belt. Review and preface to the thematic issue. Mineral Deposita 33:2-30

Locutura J, Bel-Lan A, García Cortés A, Martínez S (2012) Atlas geoquímico de España. Instituto Geológico y Minero de España, Madrid

Macklin MG (1996) Fluxes and storage of sediment-associated heavy metals in floodplain systems: assessment and river basin management issues at a time of rapid environmental change. In: Anderson MG, Walling DE, Bates PD (eds) Floodplain processes. John Wiley and Sons, Chichester, pp 441-460

Macklin MG, Ridgway J, Passmore DG, Rumsby BT (1994) The use of overbank sediment for geochemical mapping and contamination assessment: results from selected English and Welsh floodplains. Appl Geochem 9:689-700

Matys Grygar T, Popelka J (2016) Revisiting geochemical methods of distinguishing natural concentrations and pollution by risk elements in fluvial sediments. J Geochem Explor 170:39-57

Ottesen RT, Bogen J, Bolviken B, Volden T (1989) Overbank sediment: a representative sample medium for regional geochemical mapping. J Geochem Explor 32:257-277

Piper D, Bau M (2013) Normalized rare earth elements in water, sediments, and wine: identifying sources and environmental redox conditions. AJAC 4:69-83

Pizzuto JE (1987) Sediment diffusion during overbank flows. Sedimentology 34:301-317

R Core Team (2014) R: a language and environment for statistical computing. R Foundation for Statistical Computing, Vienna http:/www. R-project.org/

Ridgway J, Fligth DMA, Martiny B, Gómez-Caballero A, Macias-Romo C (1995) Overbank sediments from Central Mexico: an evaluation of their use in regional geochemical mapping and in studies of contamination from modern and historical mining. Appl Geochem 10:97-109

Roddaz M, Viers J, Moreira-Turcq P, Blondel C, Sondag F, Guyot JF, Moreira L (2014) Evidence for the control of the geochemistry of Amazonian floodplain sediments by stratification of suspended sediments in the Amazon. Chem Geol 387:101-110

Sáez R, Pascual E, Toscano M, Almodóvar GR (1999) The Iberian type of volcano-sedimentary massive sulphide deposits. Mineral Deposita 34:549-570

Sánchez España J, López Pamo E, Santofimia E, Aduvire O, Reyes J, Barettino D (2005) Acid mine drainage in the Iberian Pyrite Belt (Odiel river watershed, Huelva, SW Spain): geochemistry, mineralogy, and environmental implications. Appl Geochem 20:1320-1356

Taylor SR, McLennan SM (1985) The continental crust: its composition and evolution. Blackwell, Oxford

Taylor KG, Owens PN (2009) Sediments in urban river basins: a review of sediment-contaminant dynamics in an environmental system conditioned by human activities. J Soils Sediments 9:281-303

Walling DE, He Q, Nicholas AP (1996) Floodplains as suspended sediment sinks. In: Anderson MG, Walling DE, Bates PD (eds) Floodplain processes. John Wiley and Sons, Chichester, pp $399-440$

Wolman MG, Leopold LB (1957) River flood plains: some observations on their formation. Physiographic and hydraulic studies of Rivers. 282-c:87-108 